\title{
Multi-scale 3D characterization with dark-field x-ray microscopy
}

Simons, Hugh William; Jakobsen, Anders Clemen; Ahl, Sonja Rosenlund; Cook, Phil K.; Detlefs, Carsten; Poulsen, Henning Friis

Published in:

Acta Crystallographica. Section A: Foundations of Crystallography

Link to article, DOI:

10.1107/S2053273317087228

Publication date:

2017

Document Version

Publisher's PDF, also known as Version of record

Link back to DTU Orbit

Citation (APA):

Simons, H. W., Jakobsen, A. C., Ahl, S. R., Cook, P. K., Detlefs, C., \& Poulsen, H. F. (2017). Multi-scale 3D characterization with dark-field x-ray microscopy. Acta Crystallographica. Section A: Foundations of Crystallography, 73, C852-C852. [MS067.O01]. https://doi.org/10.1107/S2053273317087228

\section{General rights}

Copyright and moral rights for the publications made accessible in the public portal are retained by the authors and/or other copyright owners and it is a condition of accessing publications that users recognise and abide by the legal requirements associated with these rights.

- Users may download and print one copy of any publication from the public portal for the purpose of private study or research.

- You may not further distribute the material or use it for any profit-making activity or commercial gain

- You may freely distribute the URL identifying the publication in the public portal 
Hugh William Simons $^{1}$, Anders Clemen Jakobsen ${ }^{1}$, Sonja Rosenlund Ahl ${ }^{1}$, Phil Cook ${ }^{2}$, Carsten Detlefs ${ }^{2}$, Henning Friis Poulsen ${ }^{1}$

${ }^{1}$ Department Of Physics, Technical University Of Denmark, Kgs. Lyngby, Denmark, ${ }^{2}$ European Synchrotron Radiation Facility, Grenoble, France

E-mail: husimo@fysik.dtu.dk

Grain boundaries, dislocations and domain walls create structural distortions that can strongly influence both local and global properties. Understanding how and over what range these distortions occur is crucial, but requires mapping strain and symmetry at the sub-micron scale without spurious effects from the sample geometry - a major challenge for many characterization techniques. Dark-field $x$-ray microscopy is a new way to map lattice strain and inclination in 3D. It is analogous to dark-field electron microscopy in that an objective lens magnifies diffracting features of the sample; however, the use of high-energy synchrotron x-rays means that these features can be large, deeply embedded, and fully mapped in seconds to minutes. Simple reconfiguration of the $x$-ray objective lens allows intuitive zooming between different scales down to a spatial and angular resolution of $70 \mathrm{~nm}$ and $0.001^{\circ}$, respectively. The technique is broadly applicable to crystalline matter, and is demonstrated here to map subtle, symmetry-lowering distortion fields around embedded domain walls, grain boundaries, and dislocations in ferroelectric crystals, ceramics and epitaxial films. These distortions extend much further than theoretical predictions - up to several $\mu \mathrm{m}$ - and result in significant strain inhomogeneity that lowers lattice symmetry throughout the majority of the material. This ability to directly characterize complex, multiscale phenomena in-situ is a key step toward formulating and validating multiscale models that account for the entire heterogeneity of materials.

[1] Simons, H., King, A., Ludwig, W., Detlefs, C., Pantleon, W., Schmidt, S., Stöhr, F., Snigireva, I., Snigirev, A., Poulsen, H. F., (2015), Nature Communications, 6098

[2] Simons, H., Jakobsen, A. C., Ahl, S. R., Detlefs, C., \& Poulsen, H. F. (2016). MRS Bulletin, 41, 454-459

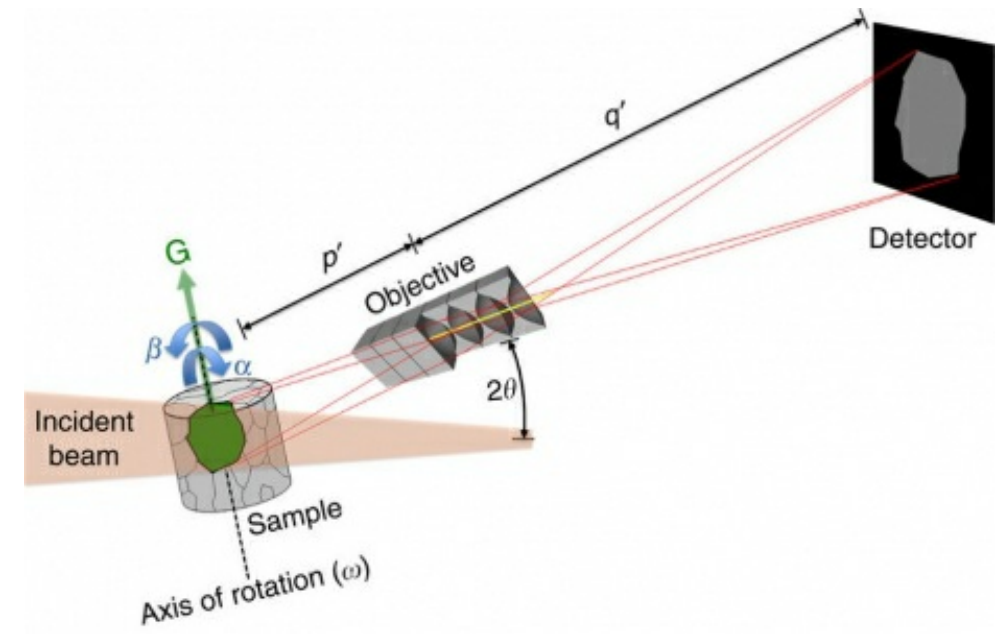

Keywords: diffraction, microscopy, ferroelectrics 